\title{
STREPTOCOCCI AND AEROCOCCI ASSOCIATED WITH SYSTEMIC INFECTION IN MAN
}

\author{
M. T. PARKer and LyN C. Ball \\ Central Public Health Laboratory, Colindale Avenue, London NW9 5HT
}

For many years, clinical microbiologists have taken little interest in the classification of streptococci isolated from septic infections unless the streptococci are $\beta$-haemolytic and belong to one of the well recognised "pyogenic" Lancefield groups. The studies of Colman and Williams (1965 and 1972; see also Colman 1968, 1969 and 1970) on a large series of laboratory strains of streptococci led us to believe that it might now be possible to classify most of the isolates from patients with systemic streptococcal disease by means of a set of cultural and biochemical tests that could be performed in a non-specialist laboratory.

At the beginning of 1972, therefore, we asked microbiologists in British hospital and public-health laboratories to send us streptococci isolated from blood cultures, cerebrospinal fluid and the internal organs of patients. In April 1972, the Epidemiological Research Laboratory of the Public Health Laboratory Service began an independent study of bacteriaemia in England and Wales, and kindly agreed to let us have their information about patients with streptococcal infections from which we had received cultures.

The present report concerns the cultures we received in the 3 years 1972-74; it describes the use of a set of tests selected from those evaluated by Colman and Williams (see Colman, 1970), and attempts to draw conclusions about the nature of the diseases associated with infection by streptococci-other than pneumococci-of the various taxonomic groups.

\section{MATERIALS AND METHODS}

\section{Cultures examined}

The isolates included in the series were all gram-positive cocci that grew aerobically (with or without the addition of $\mathrm{CO}_{2}$ ), did not give a strongly positive catalase reaction, and were not pneumococci (q.v.). They had all been obtained from the bloodstream (or a cardiac vegetation), or from a collection of pus in a thoracic or abdominal viscus (other than the gut), the peritoneal or pleural cavity, the central nervous system or a joint (table I). From many of the patients, more than one culture was submitted to us; each culture was examined fully, but only one from each patient was included in the series unless the results of the tests indicated that two distinct micro-organisms had been isolated. In all, there were $\mathbf{8 2 0}$ isolates from 813 patients, seven of whom had yielded two distinguishable micro-organisms.

Our information indicated that 12 strains were from afebrile patients with no clinical evidence of streptococcal disease; 89 others were not accompanied by a useful clinical history. There was sufficient information about the remaining 719 cultures to indicate that 
TABLE I

Origin of the cultures examined

\begin{tabular}{|c|c|c|c|c|}
\hline \multirow{3}{*}{$\begin{array}{l}\text { Clinical history } \\
\text { of patient }\end{array}$} & \multicolumn{4}{|c|}{ Number of distinct isolates from } \\
\hline & \multirow[b]{2}{*}{ blood } & \multicolumn{2}{|c|}{ internal organ* } & \multirow[b]{2}{*}{$\begin{array}{l}\text { all } \\
\text { sources }\end{array}$} \\
\hline & & $\begin{array}{l}\text { in living } \\
\text { patient }\end{array}$ & $\begin{array}{c}\text { at } \\
\text { necropsy }\end{array}$ & \\
\hline $\begin{array}{l}\text { Not available } \\
\text { No febrile illness }\end{array}$ & $\begin{array}{l}89 \\
12\end{array}$ & $\begin{array}{l}0 \\
0\end{array}$ & $\begin{array}{l}\mathbf{0} \\
\mathbf{0}\end{array}$ & $\left.\begin{array}{l}89 \\
12\end{array}\right\} 101$ \\
\hline $\begin{array}{l}\text { Endocarditis } \\
\text { Probable endocarditis } \\
\text { Meningitis } \\
\text { Other purulent disease } \\
\text { Febrile illness }\end{array}$ & $\begin{array}{c}233 \\
76 \\
6 \dagger \\
30 \ddagger \\
248\end{array}$ & $\begin{array}{r}5 \\
0 \\
63 \\
41 \\
0\end{array}$ & $\begin{array}{r}3 \\
0 \\
2 \\
10 \\
2\end{array}$ & $\left.\begin{array}{r}241 \\
76 \\
71 \\
81 \\
250\end{array}\right\} 719$ \\
\hline Total & 694 & 109 & 17 & 820 \\
\hline
\end{tabular}

* In the thorax, abdomen, central nervous system, or a joint, whether or not the blood culture was positive.

$\dagger$ Isolated from blood; sterile pus in cerebrospinal fluid.

$¥$ Isolated from blood; clinical evidence of septic lesion in an internal organ.

the 712 patients from whom they had been obtained were suffering from a febrile or septic disease that might have been attributable to the organism or organisms sent for examination.

\section{Bacteriological methods}

All the cultures were examined microscopically in gram-stained films; colonial form and haemolysis were recorded after incubation overnight at $37^{\circ} \mathrm{C}$ on blood-agar plates \{Hartley digest agar (Cowan and Steel, 1974) containing 5\% (v/v) of defibrinated horse blood and layered over peptone-water agar\}; tests for catalase production were made (Cowan and Steel, 1974, p. 171, method 1); grouping was performed with antisera for Lancefield's groups A, B, C and G (see below); and optochin-sensitivity tests were made by applying a 5- $\mu \mathrm{g}$ optochin disk (Mast Laboratories) to the surface of a blood-agar plate so inoculated as to give a growth of closely packed but discrete colonies. All optochin-sensitive streptococci were excluded from the series.

Haemolysis was defined, according to the appearances on the blood-agar plate, as $\beta$ haemolysis: clearing around the colony, whether partial or complete, if no clumps of discoloured RBC could be seen ; and $\alpha$-haemolysis: green discoloration of RBC around or under the colony, even when some clearing was present.

Seventy-two colonially typical, $\beta$-haemolytic cultures of group A, 31 of group $\mathbf{B}$, one of group $\mathrm{C}$, and three of group $\mathrm{G}$ were not subjected to any other cultural or biochemical tests. The remainder of the isolates were examined as follows; unless other conditions are mentioned incubation was at $37^{\circ} \mathrm{C}$, the inoculum was a loopful of overnight broth culture, and the broth was Todd-Hewitt broth (Cowan and Steel, 1974).

Growth aerobically, anaerobically, and in the presence of $\mathrm{CO}_{2}$. Blood-agar plates, with inocula of approximately equal size, were incubated overnight, and re-incubated for another day if growth was poor, (1) aerobically but not in a jar, (2) anaerobically in a hydrogen-filled jar, and (3) in a closed jar with a lighted candle. The presence and amount of growth and haemolysis were recorded. Organisms that grew only in the anaerobic jar were excluded from 
the series; those that grew markedly better in the candle jar than on the aerobically incubated plate were recorded as having a requirement for $\mathrm{CO}_{2}$. Our justification for this was that, when we tested a large and representative collection of cultures of Streptococcus mutans and $S$. milleri in the candle jar and in a $\mathrm{CO}_{2}$ incubator $\left(10 \% \mathrm{CO}_{2}\right.$ in air), identical results were obtained.

Lancefield grouping. Antisera for groups A, B, C, E, F, G, H, K, L, M, N, O, P, Q, R, and $S$ were made in the Streptococcus Reference Laboratory and for group $D$ by Wellcome Biological Reagents, Beckenham, Kent. In general, extracts of $\beta$-haemolytic organisms were made from overnight cultures on blood-agar plates by the enzyme method of Maxted (1948). Other cultures, and all that had not given a grouping reaction by this method, were extracted with formamide (Fuller, 1938); for this purpose we used the centrifuged deposit from $50 \mathrm{ml}$ of an overnight culture in Todd-Hewitt broth, or glucose broth \{Hartley broth (Cowan and Steel, 1974) with the addition of glucose $1.0 \% \mathrm{w} / \mathrm{v}$ \} if the streptococcus was thought to be a member of group D (Medrek and Barnes, 1962). Many cultures were also extracted by Lancefield's (1928) method ; as a routine, $0 \cdot 2 \mathrm{M} \mathrm{HCl}$ was used at $100^{\circ} \mathrm{C}$, but when unexpected negative results were obtained the test was usually repeated at a lower temperature $\left(60^{\circ} \mathrm{C}\right.$ for $2 \mathrm{~h}$ ) or with weaker acid $(0.07 \mathrm{M})$. Selected cultures of $S$. bovis were extracted by the method of Shattock (1949).

Grouping tests with the full range of antisera were performed on all the cultures except the colonially typical members of groups A, B, C and G mentioned above. Most of the tests were made by the layering method (Williams, 1958), and positive reactions appearing within $5 \mathrm{~min}$. were recorded. In 1974, some of the tests were performed in agar-gel slides by a method similar to that used by Rotta et al. (1971) for streptococcal M typing.

Growth on bile and hydrolysis of aesculin. The medium in one half of a blood-agar plate was excised and replaced by Oxoid Nutrient Agar (CM3) containing Difco Dehydrated Ox Gall (0128-01) to a concentration equivalent to $40 \%$ or $10 \%$ of bile, aesculin $0 \cdot 1 \%(\mathrm{w} / \mathrm{v})$ and ferric citrate $0.05(\mathrm{w} / \mathrm{v})$. Plates were cross-streaked, and bile tolerance was indicated by growth right across the plate after $24 \mathrm{~h}$; aesculin hydrolysis by bile-tolerant organisms caused blackening. However, all organisms were also seeded into "sugar" tubes containing aesculin $1 \%(\mathrm{w} / \mathrm{v})$, and acidification was taken as evidence of aesculin hydrolysis (Colman, 1970).

Survival for $30 \mathrm{~min}$. at $60^{\circ} \mathrm{C}$. A 7-ml screw-capped bottle containing $1.0 \mathrm{ml}$ of an overnight broth culture was totally immersed in a water bath at $60^{\circ} \mathrm{C}$ for $30 \mathrm{~min}$. and then cooled rapidly under running water; one loopful of broth was transferred to a blood-agar plate.

Growth at $45^{\circ} \mathrm{C}$. The medium was Todd-Hewitt broth, and incubation was for 5 days in a thermostatically controlled water bath with rotary paddle. Turbidity indicated growth; terminal subculture to blood agar was used as a check for purity.

Salt tolerance. Wright's broth (Cowan and Steel, 1974) with the addition of $\mathrm{NaCl} 6.5 \%$ or $4.0 \%(\mathrm{w} / \mathrm{v})$ was used. Incubation was for 5 days; turbidity indicated tolerance, and terminal subculture was performed.

Growth at $p H$ 9.6. Clarke's (1953) modification of the medium of Shattock and Hirsch (1947) was distributed aseptically into 7-ml screw-capped bottles leaving as little air space as possible. It was inoculated heavily from growth on a solid medium and incubated for 5 days. Turbidity and decolourisation indicated growth. Uninoculated controls were always included.

Arginine dihydrolase. The method of Niven, Smiley and Sherman (1942) was used (see Cowan and Steel, 1974) to test for the production of ammonia from arginine; cultures were incubated for 5 days.

Voges-Proskauer (VP) test. The organism was grown for 5 days in the medium described by Colman (1970); the test was performed by Barritt's method and read after 15 min.

Production of extracellular polysaccharide from sucrose. Cultures were grown in Bailey and Oxford's (1958) medium for 5 days and tested for the production of dextran and laevan by differential precipitation with ethanol as described by Hehre and Neill (1946; for details see Colman, 1970).

"Sugar"-fermentation tests. These were performed in Hiss's serum-water (Cowan and Steel, 1974), but with Andrade's indicator, to which 1.0\% (w/v) of the Seitz-filtered test 
TABLE II

Classification of the isolates

$\left.\begin{array}{l|r}\hline \text { Taxonomic group (and abbreviated designation) } & \text { Number of isolates } \\ \hline \text { Pyogenic streptococci } & \\ \text { Lancefield group A (Group A) } & 99 \\ \text { Lancefield group B (Group B) } & 78 \\ \text { Lancefield group C (Group C) } & 15 \\ \text { Lancefield group G (Group G) } & 25\end{array}\right\}$

substrate had been added aseptically. Results were recorded after incubation for 5 days, and all tubes were subcultured at this time.

The following tests were applied to selected groups of strains: (1) all members of Lancefield's groups A and B were serotyped, and (2) all streptococci with the cultural characters of enterococci were tested for type antigens in the $S$. faecalis series (Sharpe, 1964) and for growth and reduction on tetrazolium agar (Barnes, 1956).

\section{RESULTS}

\section{Classification of the isolates}

Most of the streptococci could be placed in a recognised taxon (table II), though many of them gave atypical reactions in individual tests; the percentage frequency of individual cultural, serological and biochemical characters in the organisms allocated to each taxonomic group is shown in tables III $a$ and III $b$.

The "pyogenic" members of Lancefield's groups A, B, C and G were usually easily recognised by their colonial appearances and $\beta$-haemolysis. A number of other streptococci reacted with the group antisera A, C and G; nearly all of these formed minute colonies $(<0.5 \mathrm{~mm}$ at $24 \mathrm{~h})$, whether or not they were $\beta$-haemolytic, gave a positive VP reaction $(\mathrm{VP}+)$ and hydrolysed aesculin $($ aesc +$)$, and were classified-as were all group-F streptococci-as 
S. milleri (Colman, 1968). Nearly one quarter of them failed to grow on blood agar without the addition of $\mathrm{CO}_{2}$ to the atmosphere.

Most of the serious difficulties concerned the allocation of strains to the predominantly " $\alpha$-haemolytic" taxa. Among the streptococci that typically formed moderate-sized colonies $(0.5-1.0 \mathrm{~mm})$ and produced greening or hazy $\beta$-haemolysis on blood agar, it was possible to recognise as $S$. sanguis (White and Niven, 1946) a group that was aesc + , attacked arginine $(\arg +)$, formed dextran $(d x+)$, fermented trehalose, lactose, salicin, inulin and sucrose but usually not raffinose or melibiose. Another group that was aesc-, arg-, $d x-$ and less often fermented trehalose, inulin or salicin, was recognisable as $S$. mitior (Schottmüller, 1903; corresponding to S. mitis of Andrewes and Horder, 1906). However, the aesculin, arginine and dextran reactions were not invariably positive in otherwise typical sanguis strains. We therefore decided arbitrarily to classify as $S$. sanguis strains that gave a positive reaction in two or more of these three tests (aesc, arg, $d x$ ) and as $S$. mitior organisms for which all three tests were negative. This had the advantage of excluding all members of Lancefield's group $\mathrm{H}$ from $S$. mitior, and left two other groups: (1) dextranpositive $S$. mitior strains $(d x+$ mitior $)$, with the reactions aesc-, arg-, $d x+$; they resemble $S$. mitior in not containing any members of group $\mathrm{H}$ but differ from it in the more frequent fermentation of raffinose and melibiose; and (2) an unclassified group ("viridans" streptococci) of $d x$ - streptococci with characters intermediate between those of $S$. sanguis and $S$. mitior.

The $S$. milleri group was composed mainly of non-haemolytic or $\beta$-haemolytic streptococci that formed minute colonies, were $d x$ - and usually aesc + , $\arg +, \mathrm{VP}+$, and had rather uniform " sugar" reactions. Some gave group-A, $-\mathrm{C},-\mathrm{F}$, or $-\mathrm{G}$ reactions but most were ungroupable. The main difficulty in defining the group was with a few very poorly growing strains that gave negative reactions in one or more of the biochemical tests in which a positive reaction was characteristic of $S$. milleri.

S. mutans strains were minute-colony-forming non-haemolytic streptococci that were fairly uniformly aesc,$+ \arg -, d x+, \mathrm{VP}+$ and had characteristic "sugar" reactions; they appeared to correspond to $S$. mutans var. mutans (Coykendall, 1974) and thus to Bratthall's (1970) serotype C of S. mutans.

The $S$. faecalis strains were nearly all biochemically typical. The few other enterococci included some members of $S$. faecium and $S$. faecium var. durans and other strains that could not be classified but did not have $S$. faecalis type antigens or reduce tetrazolium. Among the strains classified as $S$. bovis there were two biotypes: $S$. bovis biotype I (S. bovis I), which formed dextran and fermented mannitol, and $S$. bovis biotype II ( $S$. bovis II), which did not form dextran and was usually mannitol non-fermenting. These corresponded respectively to the "typical" and "atypical" $S$. bovis strains recognised by Facklam (1972) among cultures of human origin.

Among the 25 streptococci that could not be allocated to a recognisable taxon (not shown in tables III $a$ and III $b$ ) there were (1) 12 mainly $\alpha$-haemolytic, bile-sensitive, mannitol-fermenting strains the other characters of which were not uniform, and (2) 10 very poorly growing non-haemolytic strains that gave 


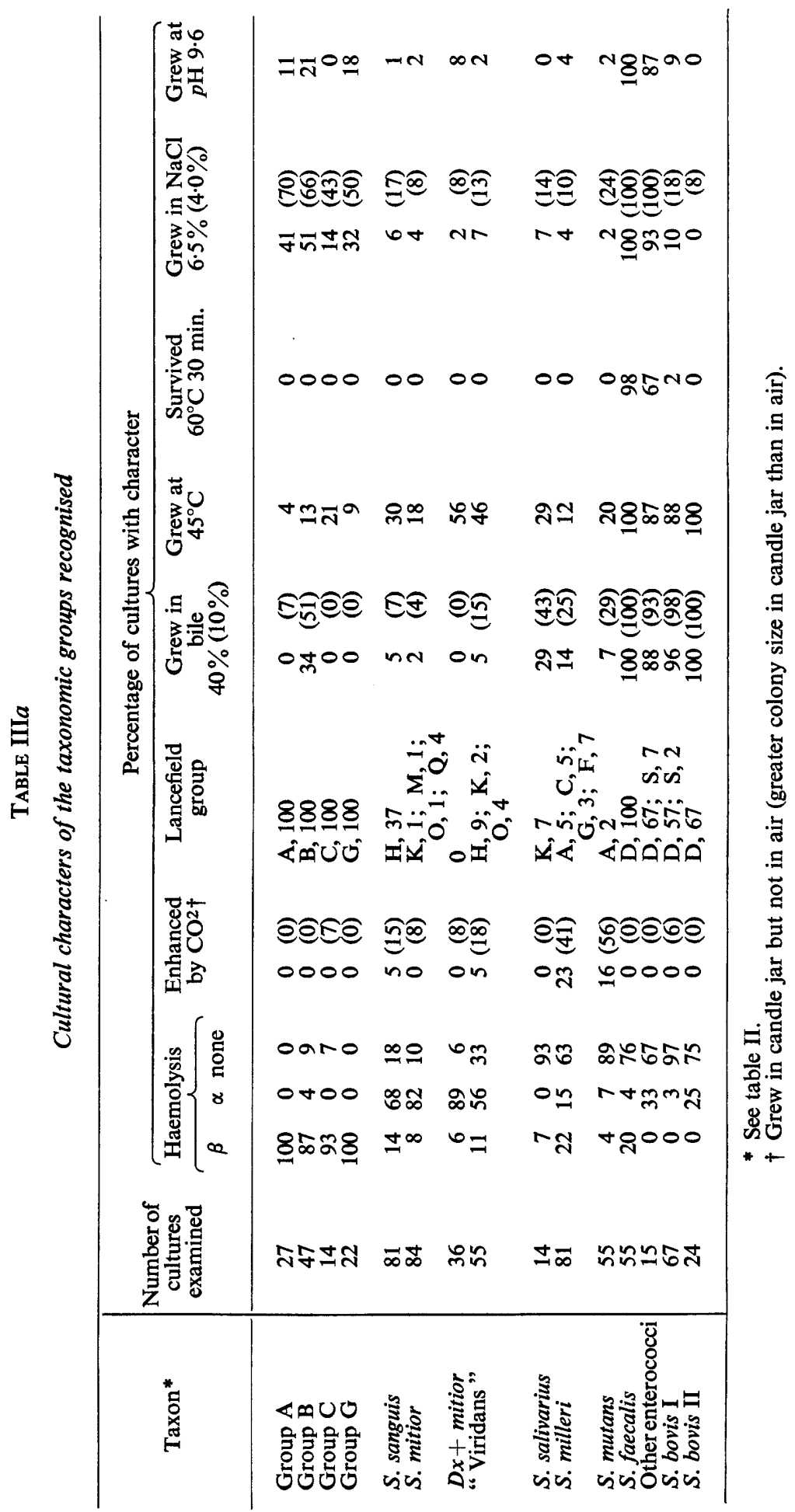




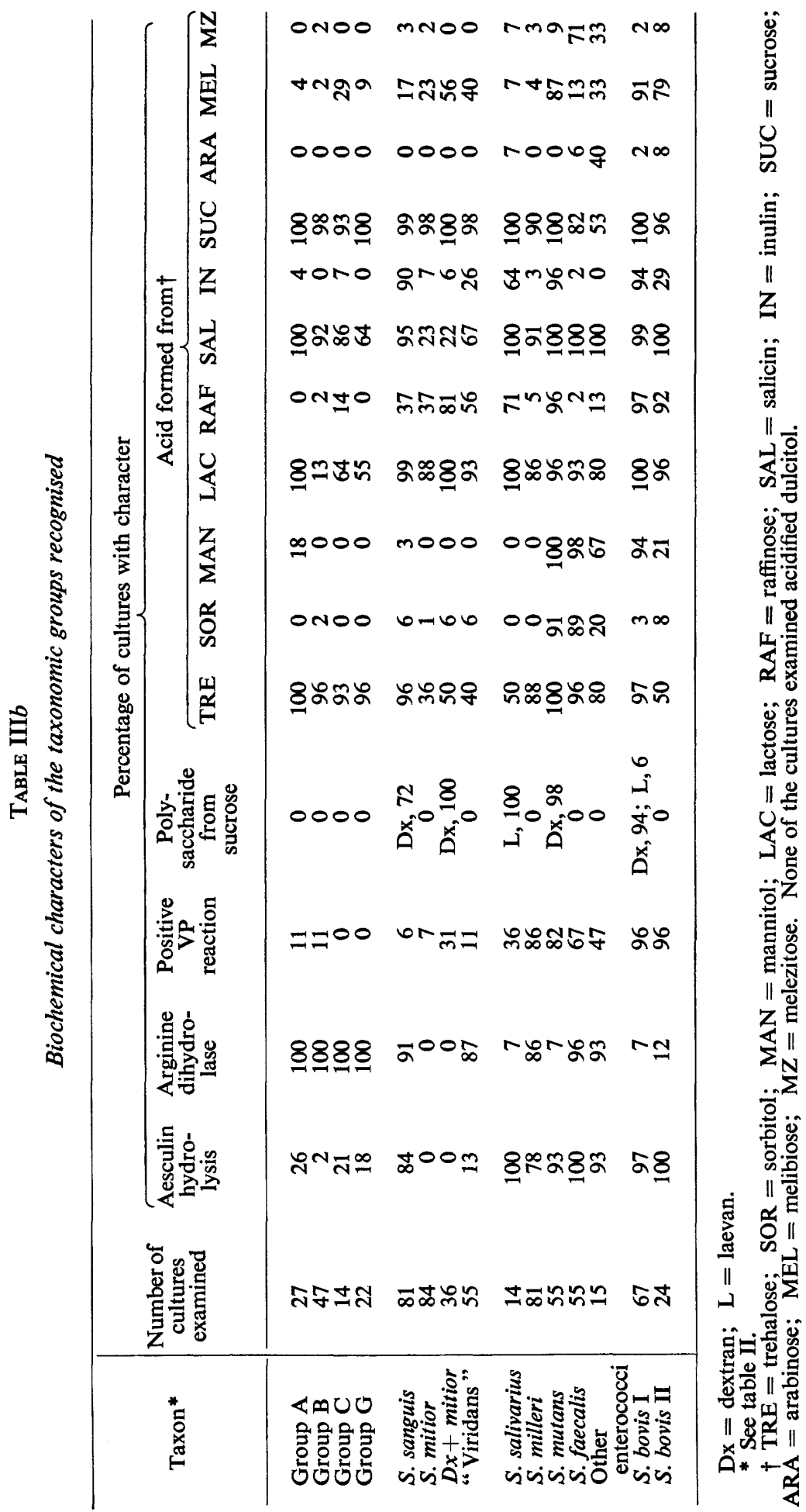


negative results in nearly all the biochemical tests, but may possibly have included some strains of $S$. milleri.

Eleven strains were finally identified as aerococci (Williams, Hirch and Cowan, 1953). Only two of them formed chains in broth culture, four of them gave a very weak catalase reaction, and all formed large colonies $>1 \mathrm{~mm}$ on blood agar, surrounded by a very prominent zone of $\alpha$-haemolysis. Their other positive characters included: growth in the presence of $40 \%$ bile (9 cultures), growth in $6.5 \% \mathrm{NaCl}$ (11 cultures) and at $p \mathrm{H} 9.6$ (10 cultures); only one culture survived for $30 \mathrm{~min}$. at $60^{\circ} \mathrm{C}$.

\section{Systemic diseases associated with the isolation of streptococci or aerococci from the blood or internal organs}

We had concluded (see Materials and methods) that 719 isolates were from patients who might have been suffering from an illness caused by the organism. They had been obtained from 712 patients during a single episode of illness in each patient; to simplify the analysis we treated each of the seven "double" isolates as if they had been responsible for a separate illness. The organisms were classified into three groups after consideration of the available clinical information about the patients and the circumstances under which the isolation had been made.

1. Endocarditis: 241 isolates ( 233 from the blood and eight from heart valves) were from patients described as suffering from "endocarditis" and 76 from the blood of patients with " probable endocarditis". Separate analysis of the two sets of cultures and the corresponding case histories showed few if any differences and the 317 will be considered together.

2. Purulent disease: 152 isolates were from patients with a clinically recognised septic lesion. Of these, 116 were from purulent material; there were also six from the bloodstream of patients who had purulent but sterile cerebrospinal fluid and 30 from the bloodstream of patients with clinical evidence of a purulent lesion in an internal organ.

3. Bacteriaemia: the remaining 250 isolates were from the blood of ill patients, nearly all of whom were febrile but none of whom showed evidence of localised infection in an internal organ.

Table IV gives the number (and percentage) of isolates from each group of patients that fell into each taxon. The isolates from endocarditis included members of all the recognised taxa of streptococci, and even a few aerococci. The most numerous were $S$. sanguis $(16.4 \%), S$. bovis I $(15 \cdot 1 \%), S$. mutans $(14.2 \%)$ and $S$. mitior $(13.2 \%)$, but these accounted for less than one-half of all the isolates. $S$. faecalis $(5.7 \%)$ and $S$. milleri $(5.4 \%)$ were isolated from smaller but still considerable numbers of patients. The four " $\alpha$ haemolytic" taxa (S. sanguis, S. mitior, $d x+$ mitior, and "viridans" streptococci), which may be equated roughly with "Streptococcus viridans" of the clinical microbiologist, formed only $44.7 \%$ of the total.

In the other systemic-disease groups, the frequency distribution of the taxa was entirely different from that in endocarditis. The most commonly isolated 
TABLE IV

Frequency of isolation of members of the different taxonomic groups in endocarditis, local purulent disease and bacteriaemia

\begin{tabular}{|c|c|c|c|c|c|}
\hline \multirow{3}{*}{ Micro-organism* } & \multicolumn{5}{|c|}{$\begin{array}{l}\text { Number of isolates of the indicated micro-organisms } \\
\text { (and percentage frequency) from patients with }\end{array}$} \\
\hline & \multirow[t]{2}{*}{ endocarditis } & \multicolumn{2}{|c|}{ purulent disease } & \multirow[t]{2}{*}{ bacteriaemia $\dagger$} & \multirow{2}{*}{$\begin{array}{c}\text { any } \\
\text { systemic } \\
\text { disease }\end{array}$} \\
\hline & & $\begin{array}{l}\text { Clinically } \\
\text { recognised }\end{array}$ & $\begin{array}{l}\text { Bacterio- } \\
\text { logically } \\
\text { confirmed }\end{array}$ & & \\
\hline $\begin{array}{l}\text { Group A } \\
\text { Group B } \\
\text { Group C } \\
\text { Group G }\end{array}$ & $\begin{array}{ll}2 & (0.6) \\
7 & (2 \cdot 2) \\
2 & (0.6) \\
5 & (1.6)\end{array}$ & $\begin{array}{rr}23 & (15 \cdot 1) \\
34 & (22 \cdot 4) \\
5 & (3 \cdot 3) \\
5 & (3 \cdot 3)\end{array}$ & $\begin{array}{rr}15 & (12.9) \\
30 & (25.9) \\
2 & (1 \cdot 7) \\
2 & (1 \cdot 7)\end{array}$ & $\begin{array}{rr}54 & (21 \cdot 3) \\
31 & (12 \cdot 2) \\
7 & (2 \cdot 8) \\
14 & (5 \cdot 5)\end{array}$ & $\begin{array}{lr}79 & (11.0) \\
72 & (10.0) \\
14 & (1.9) \\
24 & (3.3)\end{array}$ \\
\hline $\begin{array}{l}\text { S. sanguis } \\
\text { S. mitior } \\
D x+\text { mitior } \\
\text { "Viridans" }\end{array}$ & $\begin{array}{lr}52 & (16 \cdot 4) \\
42 & (13 \cdot 2) \\
23 & (7 \cdot 3) \\
25 & (7 \cdot 9)\end{array}$ & $\begin{array}{ll}8 & (5 \cdot 3) \\
4 & (2 \cdot 6) \\
0 & \\
4 & (2 \cdot 6)\end{array}$ & $\begin{array}{ll}4 & (3.4) \\
4 & (3.4) \\
0 & \\
2 & (1.7)\end{array}$ & $\begin{aligned} 14 & (5 \cdot 5) \\
24 & (9 \cdot 8) \\
9 & (3.5) \\
19 & (7 \cdot 5)\end{aligned}$ & $\begin{array}{lr}74 & (10.3) \\
71 & (9.9) \\
32 & (4.5) \\
48 & (6.7)\end{array}$ \\
\hline $\begin{array}{l}\text { S. salivarius } \\
\text { S. milleri } \\
\text { S. mutans } \\
\text { S. faecalis } \\
\text { Other enterococci } \\
\text { S. bovis I } \\
\text { S. bovis II }\end{array}$ & $\begin{array}{rr}4 & (1 \cdot 3) \\
17 & (5 \cdot 4) \\
45 & (14 \cdot 2) \\
18 & (5 \cdot 7) \\
7 & (2 \cdot 2) \\
48 & (15 \cdot 1) \\
7 & (2 \cdot 2)\end{array}$ & $\begin{array}{rr}4 & (2 \cdot 6) \\
43 & (28 \cdot 3) \\
0 & \\
3 & (2 \cdot 0) \\
2 & (1 \cdot 3) \\
4 & (2 \cdot 6) \\
4 & (2 \cdot 6)\end{array}$ & $\begin{array}{rc}4 & (3 \cdot 4) \\
34 & (29 \cdot 3) \\
0 & \\
3 & (2 \cdot 6) \\
2 & (1 \cdot 7) \\
3 & (2 \cdot 6) \\
3 & (2 \cdot 6)\end{array}$ & $\begin{aligned} 5 & (2 \cdot 0) \\
15 & (5 \cdot 5) \\
4 & (1 \cdot 6) \\
24 & (9 \cdot 4) \\
3 & (1 \cdot 2) \\
8 & (3 \cdot 1) \\
11 & (4 \cdot 3)\end{aligned}$ & $\begin{array}{lc}13 & (1 \cdot 8) \\
74 & (10 \cdot 3) \\
49 & (6 \cdot 8) \\
45 & (6 \cdot 3) \\
12 & (1 \cdot 7) \\
60 & (8 \cdot 3) \\
22 & (3 \cdot 1)\end{array}$ \\
\hline $\begin{array}{l}\text { Miscellaneous } \\
\text { streptococci }\end{array}$ & $9 \quad(2 \cdot 8)$ & $9 \quad(5 \cdot 9)$ & $8 \quad(6 \cdot 9)$ & $5 \quad(2 \cdot 0)$ & $23 \quad(3 \cdot 2)$ \\
\hline Aerococci & $4(1 \cdot 3)$ & 0 & 0 & $3(1 \cdot 2)$ & $7(1.0)$ \\
\hline $\begin{array}{l}\text { Any streptococci } \\
\text { or aerococci }\end{array}$ & 317 & 152 & 116 & 250 & 719 \\
\hline
\end{tabular}

* See table II.

$\dagger$ No clinical or bacteriological evidence of endocarditis or of purulent disease in internal organs.

organisms in clinically recognised purulent disease were $S$. milleri $(28.3 \%)$, group-B streptococci $(22.4 \%)$, group-A streptococci $(15 \cdot 1 \%)$, and " miscellaneous" streptococci $(5.9 \%)$, which together accounted for over $70 \%$ of the isolates. The " miscellaneous" streptococci, however, formed a heterogeneous group, and included both "mannitol-fermenting" and "poorly growing" strains (see table II). Small numbers of strains belonging to a variety of other taxa were isolated from purulent diseases, only $S$. mutans, $d x+$ mitior strains, and aerococci being unrepresented in this series. The frequency distribution for isolates from bacteriologically proven cases was very similar to that for all clinically recognised purulent infections, and gave the same rank order for the four most common taxa.

In bacteriaemia without evidence of localisation on heart valves or in other internal organs the most frequently isolated organisms were (1) group-A 
TABLE V

Excess or deficiency of individual taxa* among isolates from patients in different disease categories

\begin{tabular}{|c|c|c|c|c|c|}
\hline \multicolumn{6}{|c|}{ Frequency ratios $\dagger$, in rank order, of the indicated taxa in isolates from } \\
\hline \multicolumn{2}{|c|}{ endocarditis } & \multicolumn{2}{|c|}{ purulent disease } & \multicolumn{2}{|c|}{ bacteriaemia } \\
\hline $\begin{array}{l}\text { S. mutans } \\
\text { S. bovis I } \\
\text { Dx+ mitior }\end{array}$ & $\begin{array}{r}14 \cdot 2: 1 \\
5 \cdot 9: 1 \\
3 \cdot 3: 1\end{array}$ & $\begin{array}{l}\text { S. milleri } \\
\text { Group B } \\
\text { Miscellaneous } \\
\text { strentococi }\end{array}$ & $\begin{array}{l}5 \cdot 1: 1 \\
3 \cdot 3: 1 \\
2 \cdot 4: 1\end{array}$ & $\begin{array}{l}\text { Group A } \\
\text { Group G } \\
\text { S. faecalis }\end{array}$ & $\begin{array}{l}4 \cdot 0: 1 \\
2 \cdot 6: 1 \\
2 \cdot 1: 1\end{array}$ \\
\hline $\begin{array}{l}\text { S. sanguis } \\
\text { S. mitior } \\
\text { "Viridans" } \\
\text { S. faecalis } \\
\text { Miscellaneous }\end{array}$ & $\begin{array}{l}3 \cdot 0: 1 \\
1 \cdot 8: 1 \\
1 \cdot 4: 1 \\
1: 1 \cdot 2 \\
1: 1 \cdot 3\end{array}$ & $\begin{array}{l}\text { Group A } \\
\text { Group G } \\
\text { S. bovis II } \\
\text { S. sanguis } \\
\text { “ Viridans " }\end{array}$ & $\begin{aligned} & 1 \cdot 5: 1 \\
& 1: 1 \cdot 1 \\
& 1: 1 \cdot 2 \\
& 1: 2 \cdot 2 \\
& 1: 3 \cdot 0\end{aligned}$ & $\begin{array}{l}\text { S. bovis II } \\
\text { Group B } \\
\text { "Viridans " } \\
\text { S. mitior } \\
\text { Dx+ mitior }\end{array}$ & $\begin{array}{l}1 \cdot 9: 1 \\
1 \cdot 4: 1 \\
1 \cdot 2: 1 \\
1: 1 \\
1: 1 \cdot 4\end{array}$ \\
\hline $\begin{array}{l}\text { streptococc1 } \\
S . \text { bovis II }\end{array}$ & $1: 1 \cdot 7$ & S. faecalis & $1: 3 \cdot 7$ & $\begin{array}{r}\text { Miscellaneous } \\
\text { streptococci }\end{array}$ & $1: 1 \cdot 9$ \\
\hline $\begin{array}{l}S . \text { milleri } \\
\text { Group G } \\
\text { Group B } \\
\text { Group A }\end{array}$ & $\begin{array}{l}1: 2 \cdot 6 \\
1: 2 \cdot 9 \\
1: 7 \cdot 4 \\
1: 32 \cdot 0\end{array}$ & $\begin{array}{l}\text { S. bovis I } \\
\text { S. mitior } \\
\text { Dx + mitior } \\
\text { S. mutans }\end{array}$ & $\begin{array}{c}1: 3 \cdot 8 \\
1: 4 \cdot 5 \\
\vdots \\
\vdots\end{array}$ & $\begin{array}{l}S . \text { sanguis } \\
S . \text { milleri } \\
S . \text { bovis I } \\
S . \text { mutans }\end{array}$ & $\begin{array}{l}1: 2 \cdot 3 \\
1: 2 \cdot 3 \\
1: 3 \cdot 6 \\
1: 6 \cdot 0\end{array}$ \\
\hline
\end{tabular}

* Comprising $>20$ isolates; for designations of taxa see table II.

$\dagger$ Ratio of percentage frequency for patients in the disease category: percentage frequency for patients not in this category.

$\$$ No isolates from purulent disease.

streptococci $(21 \cdot 3 \%)$, (2) group-B streptococci $(12 \cdot 2 \%)$, (3) S. mitior $(9 \cdot 8 \%)$, and (4) $S$. faecalis $(9 \cdot 4 \%) ; 26.3 \%$ belonged to the four " $\alpha$-haemolytic " taxa.

Table $\mathrm{V}$ shows, for the more common taxa, the ratios of the percentage frequency of isolations from patients in each disease group to that from patients in the other two disease groups; these may be taken to reflect the ability of streptococci that reach the bloodstream or an internal organ (1) to cause endocarditis, (2) to give rise to a purulent lesion, or (3) to do neither. Thus, the four taxa $S$. mutans, S. bovis I, $d x+$ mitior, and $S$. sanguis were markedly more common $(>3: 1)$ in endocarditis than in other systemic infections. Indeed, $S$. mutans was very rarely found in the bloodstream except in endocarditis; S. mitior and "viridans" streptococci, on the other hand, were not greatly more frequent among endocarditis than among "nonendocarditis " isolates. At the other extreme, systemic infections with group-A streptococci (ratio $1: 32$ ) and group-B streptococci (ratio $1: 7 \cdot 4$ ) seldom led to endocarditis.

All four of the taxa with a frequency-ratio for endocarditis of $>3: 1$ are typically dextran producers, and none of the taxa with lower ratios contained any dextran-forming streptococci. The contrast between the ratios for S. bovis I $(d x+; 5.9: 1)$ and $S$. bovis II $(d x-; 1: 1.7)$ is noteworthy in this respect. Dextran production was detected in over $90 \%$ of all strains classified as $S$. mutans, $S$. bovis I, and $d x+$ mitior streptococci. In $S$. sanguis, however, we had included a number of $d x-$ strains because they resembled this species 
TABLE VI

Frequency of isolation of members of the different taxonomic groups in purulent diseases of various organs

\begin{tabular}{|c|c|c|c|c|c|}
\hline \multirow[t]{2}{*}{ Micro-organism* } & \multicolumn{5}{|c|}{$\begin{array}{l}\text { Number of isolates of the indicated micro-organisms from a } \\
\text { lesion (or from the blood with clinical evidence of a septic } \\
\text { lesion) in }\end{array}$} \\
\hline & meninges & brain & abdomen & thorax & bone or joint \\
\hline $\begin{array}{l}\text { Group A } \\
\text { Group B } \\
\text { Group C } \\
\text { Group G }\end{array}$ & $\begin{array}{r}5(1) \\
30(3) \\
1 \\
2\end{array}$ & $\begin{array}{l}1 \\
0 \\
1 \\
0\end{array}$ & $\begin{array}{l}2(1) \\
0 \\
0 \\
0\end{array}$ & $\begin{array}{l}7(1) \\
0 \\
0(1) \\
0(3)\end{array}$ & $\begin{array}{l}0(5) \\
0(1) \\
0(1) \\
0\end{array}$ \\
\hline $\begin{array}{l}\text { S. sanguis } \\
\text { S. mitior } \\
\text { Dx+ mitior, } \\
\text { "Viridans" }\end{array}$ & $\begin{array}{l}2(1) \\
2 \\
0 \\
1 \dagger\end{array}$ & $\begin{array}{l}0 \\
1 \\
0 \\
0\end{array}$ & $\begin{array}{l}0(2) \\
0 \\
0 \\
0\end{array}$ & $\begin{array}{l}2 \\
0 \\
0 \\
1(3) \dagger\end{array}$ & $\begin{array}{l}0(1) \\
1 \\
0 \\
0\end{array}$ \\
\hline $\begin{array}{l}\text { S. salivarius } \\
\text { S. milleri } \\
\text { S. mutans } \\
\text { S. faecalis } \\
\text { Other enterococci } \\
\text { S. bovis } \\
\text { S. bovis II }\end{array}$ & $\begin{array}{l}3 \\
8 \\
0 \\
1 \\
1 \\
3 \\
3\end{array}$ & $\begin{array}{c}0 \\
13(1) \ddagger \\
0 \\
0 \\
0 \\
0 \\
0\end{array}$ & $\begin{array}{l}0 \\
7 \\
0 \\
1 \\
1 \\
0 \\
0 \\
0\end{array}$ & $\begin{array}{l}1 \\
6(1) \ddagger \\
0 \\
1 \\
0 \\
0(1) \\
0(1)\end{array}$ & $\begin{array}{l}0 \\
0 \\
0 \\
0 \\
0 \\
0 \\
0\end{array}$ \\
\hline $\begin{array}{l}\text { Miscellaneous } \\
\text { streptococci }\end{array}$ & 3 & 0 & $1(1)$ & 4 & 0 \\
\hline Aerococci & 0 & 0 & 0 & 0 & 0 \\
\hline Any streptococci & $65(6)$ & $16(1)$ & $12(11)$ & $22(11)$ & $1(9)$ \\
\hline
\end{tabular}

closely in other ways (table III b). Of $53 \mathrm{~S}$. sanguis strains with a positive dextran reaction, 42 had been isolated from cases of endocarditis, giving a frequency ratio of $4 \cdot 9: 1$. For all dextran-forming " $\alpha$-haemolytic "streptococci $(d x+$ mitior and dextran-forming $S$. sanguis strains) the ratio was $4 \cdot 1: 1$; and for all dextran-negative " $\alpha$-haemolytic" streptococci (S. mitior, "viridans", and the dextran-negative $S$. sanguis strains) it was $1.5: 1$.

The frequency ratios emphasised the importance of $S$. milleri and group-B streptococci as causes of purulent disease. Group-A streptococci, on the other hand, were more prominent as causes of " uncomplicated " septicaemia than of purulent lesions in internal organs. Table VI shows the anatomical distribution of purulent lesions caused by the various streptococci. Group-B streptococci were isolated from pus almost exclusively from the meninges, but $S$. milleri and group A streptococci were found in pus in a variety of organs. S. milleri was isolated from 13 of 16 streptococcal brain abscesses and from 8 of 65 bacteriologically confirmed cases of streptococcal meningitis, though in several of these 
TABLE VII

Age and sex of 223 endocarditis patients*

\begin{tabular}{|c|c|c|c|}
\hline \multirow{2}{*}{ Micro-organism $\dagger$} & \multicolumn{3}{|c|}{$\begin{array}{c}\text { Number (and percentage) of isolates of the stated micro- } \\
\text { organism from patients aged (years) }\end{array}$} \\
\hline & $10-34$ & $35-54$ & $>55$ \\
\hline S. sanguis & $M=\stackrel{10}{7} ; \quad F=3$ & $M=11 ; \quad F=4$ & $M=\stackrel{19}{5} ; \quad F=14$ \\
\hline S. mitior & $M=\stackrel{4}{2} ; F=2$ & $M=\frac{15}{10 ;} F=5$ & $M=14 ; \quad F=3$ \\
\hline$D x+$ mitior & $M=\stackrel{9}{6} ; F=3$ & $M=2 ; \quad F=0$ & $M=\stackrel{6}{4} ; F=2$ \\
\hline “Viridans" & $\mathrm{M}=\stackrel{4}{4} ; \mathrm{F}=0$ & $M=\stackrel{8}{7} ; F=1$ & $M=\stackrel{6}{4} ; F=2$ \\
\hline All " $\alpha$-haemolytic" taxa & $M=19 ; \stackrel{27}{F}=8$ & $M=26 ; \quad F=10$ & $M=24 ; \quad F=21$ \\
\hline S. mutans & $\mathrm{M}=4 ; \mathrm{F} \stackrel{\mathrm{F}}{=}=1$ & $\mathrm{M}=16 ; \mathrm{F} ; \mathrm{F}=1$ & $M=6 ; \stackrel{F}{F}=5$ \\
\hline S. bovis I & $\mathrm{M}=\stackrel{1}{0} \stackrel{(2 \cdot 6)}{\mathrm{F}}=1$ & $M=\underset{7}{6} ; \stackrel{(9 \cdot 3)}{F}=1$ & $\mathrm{M}=15 ; \stackrel{23.9)}{\mathrm{F}}=11$ \\
\hline Any other & $M=4 ; F=2$ & $M=9 ; \quad F=6$ & $M=19 ; F=8$ \\
\hline Any & $\mathrm{M}=27 ; \mathrm{F}=12$ & $M=57 ; \quad F=18$ & $M=64 ; F=45$ \\
\hline
\end{tabular}

pus formation was limited to part of the brain surface. It was also isolated from the lesion or the blood in five cases of empyema, four of peritonitis, four of liver abscess (including two of those described by Bateman, Eikyn and Phillips, 1975), and one each of lung abscess and perinephric abscess.

Multiple isolations from patients. Seven pairs of isolates in our series had been obtained from the same patient, and blood cultures of two other patients yielded cultures described as $S$. faecalis that were not sent to us. In all, therefore, two different streptococcal strains were isolated from nine of 712 patients; and 11 other organisms were reported to have been grown from the blood of 10 of the patients (coliform bacilli, four; Proteus sp., two; coagulase-positive staphylococci, two; and other staphylococci, Pseudomonas aeruginosa and Candida sp., one each).

The frequency with which a streptococcal or aerococcal strain was isolated in association with any other organism, in the same disease episode and from the blood or an internal organ, was high for $S$. mitior (6 of 84 isolations), $S$. faecalis (6 of 55 isolations), "viridans" streptococci (6 of 55 isolations) and aerococci ( 2 of 7 isolations). 


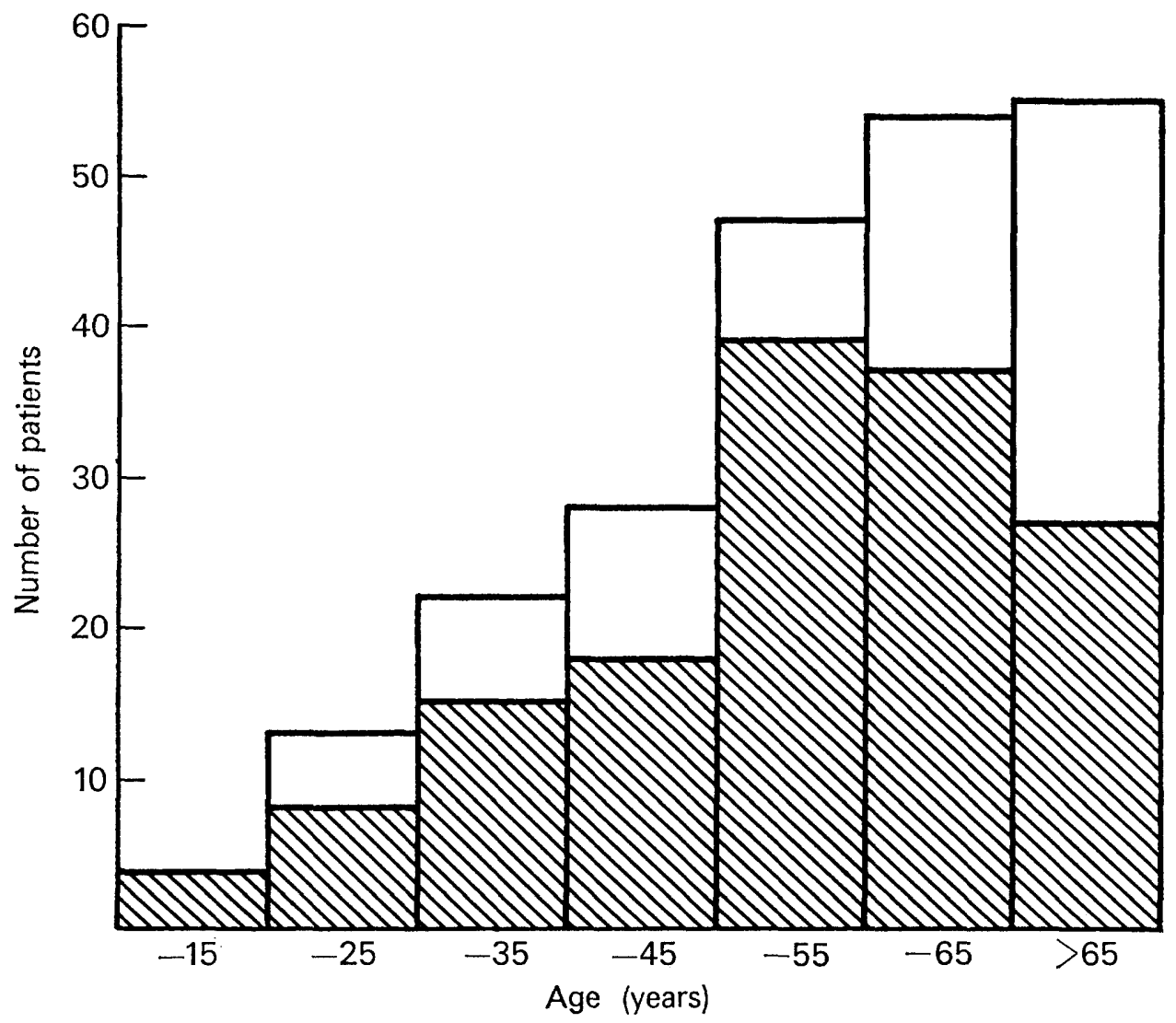

FIGURE.-Age and sex distribution of endocarditis patients from whom the isolates had been obtained. Age groups: $-15=$ up to the 15 th birthday; $-25=$ from then up to the 25 th birthday; and so on. $\square=$ males; $\square=$ females.

\section{Predisposing factors in endocarditis}

Age and sex. Accurate information about the age and sex of endocarditis patients was available in respect of only 223 of the 317 patients. In this series (the figure), there was an increase in the number of patients in each successive 10-year cohort, and a considerable excess of males over females, up to the age of 65 years. All four of the patients aged less than 15 years were males, the youngest of whom was aged 10 years. After the age of 65 years, male and female patients were approximately equal in numbers.

Conclusions about the age and sex of patients with endocarditis associated with streptococci of individual taxa (table VII) must be tentative, because the total numbers in each taxon were rather small. There was, however, a considerable decrease with increasing age in the proportion of cases yielding streptococci of the four " $\alpha$-haemolytic" taxa from $69.2 \%$ at ages $<35$ years, to $48.0 \%$ between the ages of 35 and 54 years, and $41.3 \%$ at ages $>55$ years, but the absolute number of isolates of " $\alpha$-haemolytic" streptococci rose slightly with 
TABLE VIII

History of previous damage to heart valves in endocarditis patients

\begin{tabular}{|c|c|c|c|c|}
\hline \multirow{2}{*}{ Micro-organism* } & \multirow{2}{*}{$\begin{array}{l}\text { Number of } \\
\text { patients }\end{array}$} & \multicolumn{3}{|c|}{$\begin{array}{l}\text { Percentage of patients yielding the } \\
\text { stated micro-organism who had a } \\
\text { history of previous }\end{array}$} \\
\hline & & $\begin{array}{l}\text { damage to } \\
\text { heart valves }\end{array}$ & $\begin{array}{c}\text { cardiac } \\
\text { operation }\end{array}$ & $\begin{array}{l}\text { endo- } \\
\text { carditis }\end{array}$ \\
\hline $\begin{array}{l}\text { S. sanguis } \\
\text { S. mitior } \\
\text { Dx+ mitior } \\
\text { "Viridans" } \\
\text { Group A, C or G } \\
\text { S. mutans } \\
\text { S. bovis I } \\
\text { S. milleri } \\
\text { S. faecalis } \\
\text { Other streptococci or } \\
\text { aerococci } \dagger\end{array}$ & $\begin{array}{l}52 \\
42 \\
23 \\
25 \\
16 \\
45 \\
48 \\
17 \\
18 \\
31\end{array}$ & $\begin{array}{c}38 \cdot 5 \\
26 \cdot 2 \\
26 \cdot 1 \\
36 \cdot 0 \\
18 \cdot 7 \\
17 \cdot 8 \\
16 \cdot 7 \\
17 \cdot 6 \\
0 \\
19 \cdot 3\end{array}$ & $\begin{array}{r}13 \cdot 4 \\
4 \cdot 8 \\
4 \cdot 3 \\
8 \cdot 0 \\
12 \cdot 5 \\
0 \\
2 \cdot 1 \\
11 \cdot 8 \\
0 \\
9 \cdot 7\end{array}$ & $\begin{array}{c}9 \cdot 6 \\
2.4 \\
4 \cdot 3 \\
16 \cdot 0 \\
0 \\
4.4 \\
4 \cdot 2 \\
0 \\
0 \\
6 \cdot 4\end{array}$ \\
\hline All " $\alpha$-haemolytic" taxa & 142 & $32 \cdot 4$ & $8 \cdot 4$ & $7 \cdot 7$ \\
\hline Any other & 175 & $16 \cdot 0$ & $4 \cdot 6$ & $3 \cdot 4$ \\
\hline $\begin{array}{l}\text { Any streptococci or } \\
\text { aerococci }\end{array}$ & 317 & $23 \cdot 3$ & $6 \cdot 3$ & $5 \cdot 4$ \\
\hline
\end{tabular}

* See table II.

$\dagger$ Group B, S. salivarius, other enterococci, S. bovis II, miscellaneous streptococci, and aerococci.

$\ddagger S$. sanguis, $S$. mitior, $d x+$ mitior and "viridans" streptococci.

increasing age. After the age of 35 years, however, there was a steeper and progressive rise in the number of isolations of other streptococci, among which $S$. mutans and $S$. bovis I were prominent. The greatest percentage frequency of $S$. mutans endocarditis $(22.6 \%)$ was between the ages of 35 and 54 years, and of endocarditis due to $S$. bovis I $(23.9 \%)$ and "any other" micro-organisms $(24.7 \%)$ at ages $>55$ years. The "other" organisms associated with endocarditis in the older patients were various, and included $S$. milleri, which caused nine cases of endocarditis in patients aged $>35$ years and none in younger patients.

There was a predominance of males over females up to the age of 55 years in endocarditis associated with all the common sorts of streptococci. At ages $>55$ years, $S$. sanguis showed an excess of females over males, but streptococci of all $\alpha$-haemolytic taxa, $S$. mutans and $S$. bovis were almost equally distributed between the sexes.

Previous damage to heart valves. Seventy-four of the 317 endocarditis patients $(23.3 \%)$ gave a history of an abnormality of the heart valves before the onset of the current illness; these included $20(6 \cdot 3 \%)$ who had had a previous operation on the heart and $17(5.4 \%)$ who had had an earlier attack of endocarditis (table VIII). The figures were too small for many conclusions to be 
TABLE IX

Age and sex of patients with other systemic infections*

\begin{tabular}{|c|c|c|c|c|c|c|c|}
\hline \multirow{3}{*}{ Micro-organism $\dagger$} & \multicolumn{6}{|c|}{$\begin{array}{l}\text { Number of isolations of the stated micro-organisms } \\
\text { from patients }\end{array}$} & \multirow{3}{*}{$\begin{array}{l}\text { Sex } \\
\text { ratiol } \\
(\mathrm{M}: \mathrm{F})\end{array}$} \\
\hline & \multicolumn{5}{|c|}{ aged (years) $\ddagger$} & \multirow{2}{*}{$\begin{array}{l}\text { of any } \\
\text { age§ }\end{array}$} & \\
\hline & $-6 / 52$ & -15 & -35 & -55 & $>55$ & & \\
\hline $\begin{array}{l}\text { Group A, C or G } \\
\text { Group B } \\
\text { “ } \alpha \text {-Haemolytic" taxa } \\
\text { S. milleri } \\
\text { Any enterococci } \\
\text { S. bovis I } \\
\text { S. bovis II } \\
\text { Any other }\end{array}$ & $\begin{array}{r}1 \\
36 \\
7 \\
1 \\
3 \\
0 \\
6 \\
1\end{array}$ & $\begin{array}{r}15 \\
3 \\
24 \\
5 \\
5 \\
3 \\
1 \\
11\end{array}$ & $\begin{array}{r}10 \\
6 \\
13 \\
9 \\
2 \\
1 \\
1 \\
2\end{array}$ & $\begin{array}{r}12 \\
4 \\
11 \\
12 \\
4 \\
0 \\
0 \\
1\end{array}$ & $\begin{array}{r}36 \\
7 \\
20 \\
15 \\
10 \\
7 \\
4 \\
11\end{array}$ & $\begin{array}{l}74 \\
56 \\
75 \\
42 \\
24 \\
11 \\
12 \\
26\end{array}$ & $\begin{array}{rr}31: & 42 \\
11: & 9 \\
36: & 32 \\
33: & 8 \\
11: & 10 \\
6: & 5 \\
3: & 3 \\
12: & 13\end{array}$ \\
\hline $\begin{array}{l}\text { All streptococci and } \\
\text { aerococci }\end{array}$ & 55 & 67 & 44 & 44 & 110 & 320 & $143: 122$ \\
\hline
\end{tabular}

* Purulent infections and bacteriaemia, but not endocarditis.

$\dagger$ See table II.

T The symbol-indicates up to but not including the year, or fraction of a year, indicated.

\$ Age not known: 82.

II In patients aged $>6$ weeks.

I $S$. salivarius, $S$. mutans, miscellaneous streptococci, and aerococci.

drawn about the frequency of previous heart damage in cases associated with single streptococcal taxa. However, in 142 attacks of endocarditis associated with streptococci of the four " $\alpha$-haemolytic" taxa, $32.4 \%$ of the patients gave a history of pre-existing valvular abnormality, $8.4 \%$ of a previous heart operation and $7.7 \%$ of earlier endocarditis; in 175 attacks associated with other streptococci (or aerococci), the corresponding percentages were respectively $16 \cdot 0,4 \cdot 6$ and $3 \cdot 4$.

Serious underlying disease. Only six of the endocarditis patients $(1.9 \%)$ were said to be suffering from other serious illnesses that might have been looked upon as predisposing factors; the illnesses (and the respective streptococci isolated) were: (1) Hodgkin's disease (a group-B streptococcus); (2) superior mesenteric thrombosis (a group-G streptococcus); (3) carcinoma of the colon (S. milleri); (4) chronic renal failure (S. mutans); (5) disseminated lupus erythematosus (S. sanguis) and (6) recent stroke (S. salivarius).

Local factors that might have been responsible for the initial infection were mentioned in relation to only $13(4 \cdot 1 \%)$ of the endocarditis cases. Two, one due to a group-B streptococcus and the other to a $d x+$ mitior strain, followed recent childbirth. Nine were recognised sufficiently soon after a surgical procedure to suggest that the infecting organism had been introduced at that time; six of these were associated with an operation on the heart (three due to streptococci of the " $\alpha$-haemolytic " taxa and one each to streptococci of groups A, B and G); the three remaining cases were associated respectively with 
TABLE X

Serious underlying disease in patients with other systemic infections*

\begin{tabular}{|c|c|c|c|c|c|c|c|c|}
\hline \multirow[b]{2}{*}{ Micro-organism $\dagger$} & \multirow[b]{2}{*}{$\begin{array}{c}\text { Total } \\
\text { number of } \\
\text { infections }\end{array}$} & \multicolumn{7}{|c|}{ Number of infections associated with the stated micro-organisms in patients also suffering from } \\
\hline & & carcinoma & $\begin{array}{l}\text { leukaemia, } \\
\text { Hodgkin's } \\
\text { disease or } \\
\text { agranulo- } \\
\text { cytosis }\end{array}$ & $\begin{array}{l}\text { diabetes } \\
\text { mellitus }\end{array}$ & $\begin{array}{c}\text { renal } \\
\text { failure }\end{array}$ & $\begin{array}{l}\text { myocardial } \\
\text { infarction } \\
\text { or stroke }\end{array}$ & $\begin{array}{l}\text { other } \\
\text { diseases }\end{array}$ & $\begin{array}{l}\text { any serious } \\
\text { underlying } \\
\text { disease }\end{array}$ \\
\hline \multirow{2}{*}{$\begin{array}{l}\text { Group A, C or G } \\
\text { Group B } \\
\text { "a-Haemolytic" } \\
\text { taxa } \\
\text { S. milleri } \\
\text { Any enterococci } \\
\text { Any other" }\end{array}$} & $\begin{array}{r}108 \\
65 \\
83\end{array}$ & $\begin{array}{l}4 \\
1 \\
1\end{array}$ & $\begin{array}{l}4 \\
0 \\
8\end{array}$ & $\begin{array}{l}6 \\
1 \\
3\end{array}$ & $\begin{array}{l}1 \\
1 \\
1\end{array}$ & $\begin{array}{l}2 \\
0 \\
3\end{array}$ & $\begin{array}{l}3 \\
0 \\
0\end{array}$ & $\begin{array}{r}20 \\
3 \\
16\end{array}$ \\
\hline & $\begin{array}{l}57 \\
32 \\
57\end{array}$ & $\begin{array}{l}1 \\
2 \\
0\end{array}$ & $\begin{array}{l}1 \\
0 \\
5\end{array}$ & $\begin{array}{l}0 \\
2 \\
0\end{array}$ & $\begin{array}{l}1 \\
2 \\
0\end{array}$ & $\begin{array}{l}1 \\
2 \\
2\end{array}$ & $\begin{array}{l}0 \\
0 \\
0\end{array}$ & $\begin{array}{l}4 \\
8 \\
7\end{array}$ \\
\hline $\begin{array}{l}\text { Any streptococci } \\
\text { or aerococci }\end{array}$ & 402 & 9 & 18 & 12 & 6 & 10 & 3 & 58 \\
\hline
\end{tabular}

- See footnote to table VIII.

† See table II.

hysterectomy ( $S$. milleri), rupture of the oesophagus during oesophagoscopy ( $S$. milleri) and laparotomy (a group-G streptococcus). Two of the patients (one infected with $S$. faecalis and the other with a "viridans" streptococcus) habitually took drugs intravenously, but the latter infection was a second attack of endocarditis. A history of recent dental extraction was given by a number of the patients, but the information given was too vague and incomplete for analysis.

\section{Predisposing factors in bacteriaemic and purulent systemic infections}

Age and sex. The age of 320 of the 402 other patients was known (table IX); $55(17.2 \%)$ infections occurred in the first 6 weeks of life and another $20(5.0 \%)$ in the rest of the 1 st year, but only $51(16.0 \%)$ in the next 14 years. Thereafter the frequency was even less until the age of 55 years, averaging about $7 \%$ per decade; $31 \cdot 2 \%$ of the patients were aged over 55 years.

Neonatal infections were predominately associated with group-B streptococci (36 of 55), which were responsible for 24 cases of meningitis-all the streptococcal neonatal meningitis recorded-and 12 of septicaemic disease without meningitis. The only other considerable group of isolates belonging to a single streptococcal taxon was of six $S$. bovis II strains from infants described as suffering from neonatal jaundice (three), neonatal distress (two) and " feeding problems" (one). Apart from one case of acute group-A streptococcal septicaemia, the rest of the infants-including the seven who yielded a streptococcus belonging to the " $\alpha$-haemolytic " taxa-gave similar rather indeterminate histories. Information about the sex of the newborn infants was incomplete and has been omitted.

Isolations of streptococci of the " $\alpha$-haemolytic" taxa were rather common in childhood, when endocarditis was rare; the respective numbers of endocarditis and "non-endocarditis" isolates from patients in each age-group 


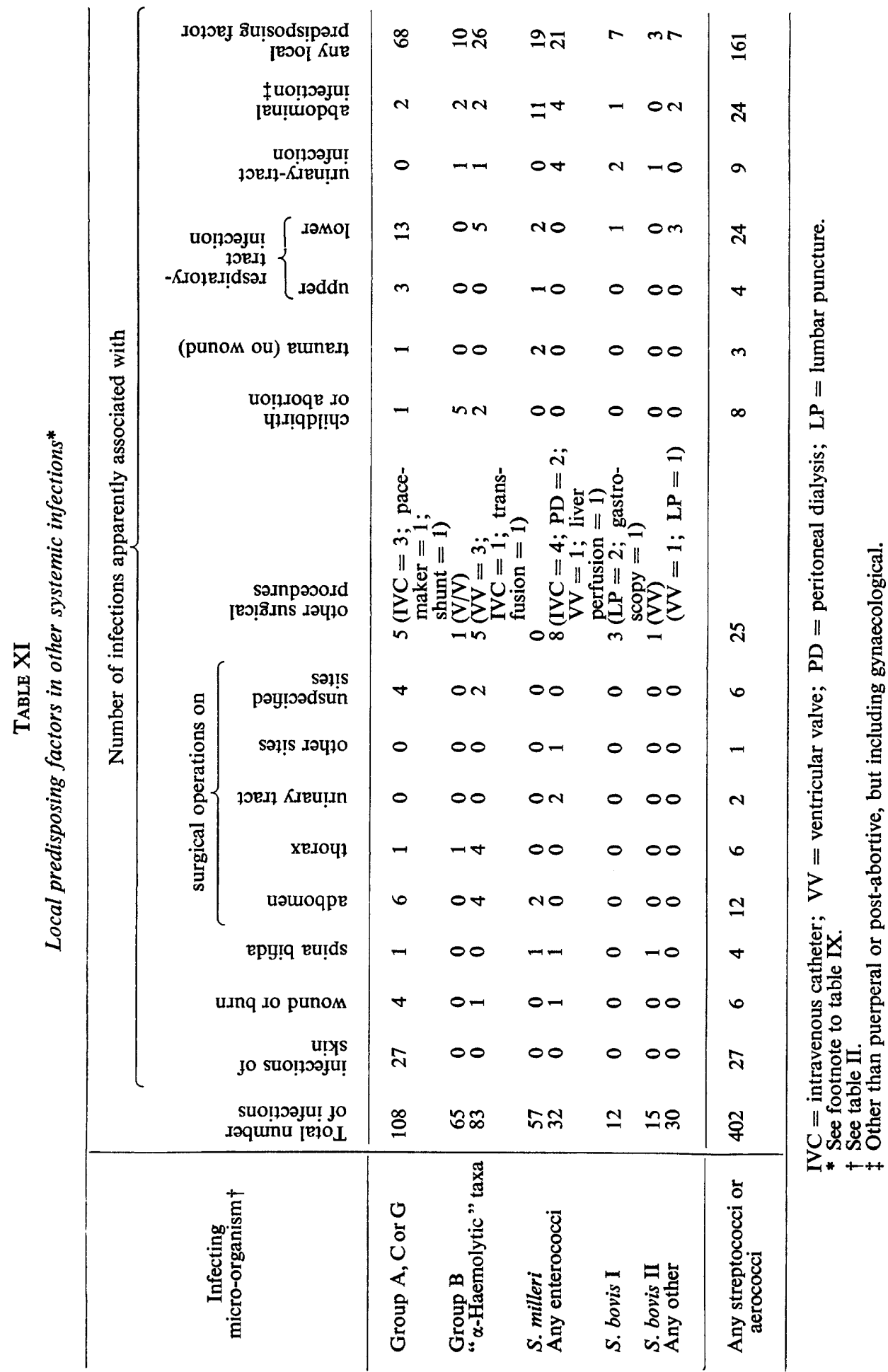

J. MED. MICROBIOL.-VOL. 9 (1976) 
were $<6$ weeks to 14 years, 3 and $24 ; 15$ to 34 years, 24 and $13 ; 35$ to 54 years, 36 and 11 ; $>55$ years, 45 and 20 . Most of the "non-endocarditis" isolates were from patients suffering from indefinite febrile illnesses, but a few were from purulent lesions, including meningitis. S. milleri isolates, whether from patients with bacteriaemia or from purulent lesions, tended to become more numerous with increasing age.

Serious underlying disease. We have seen that pre-existing diseases, other than damage to the heart valves, appeared to play little part in determining the occurrence of streptococcal endocarditis. They were somewhat more important in purulent and bacteriaemic systemic infections (table $\mathrm{X}$ ), being mentioned in relation to 58 of the 402 isolates $(14.4 \%)$; the corresponding figure for endocarditis was $1.9 \%$.

Infections with streptococci of groups $A$ and $G$ were often associated with serious underlying disease: 14 of 77 group-A infections (18.2\%) and 6 of 19 group-G infections $(31.6 \%)$. These, and the enterococcal infections, usually gave rise to clear-cut septicaemic illnesses. The rather numerous isolations of members of the " $\alpha$-haemolytic" groups, and of "other" streptococci, especially from patients with leukaemia and Hodgkin's disease, were rather more difficult to interpret; many, but by no means all of them, appear to have been intercurrent events in severely ill patients.

In a number of instances, however, the predisposing effect of the underlying disease appears to have been local rather than general. Thus, of 27 infections associated with carcinoma, leukaemia, Hodgkin's disease or agranulocytosis, five were obviously nosocomial (four instances of meningitis in patients under treatment for leukaemia and one of wound infection and septicaemia after the surgical removal of a carcinoma), and six may have resulted from local infection of a carcinomatous growth (three in the gut, two in the urinary tract and one in the nasopharynx).

Local factors. Table XI summarises information about local events that preceded the development of a disease (other than endocarditis) in which a streptococcus or aerococcus was isolated from the bloodstream or an internal organ. Such an event was recorded for 161 of 402 infections $(40.0 \%)$; the corresponding percentage for endocarditis was $4 \cdot 1$. On the left of the table are infections in which the organism may have gained entry through the skin or a wound, and on the right those in which infection appeared to have begun in a particular organ. It must be emphasised, however, that the infecting microorganism was isolated from the supposed site of entry in only a minority of the patients.

A local event that gave an indication of the probable entry-point was identifiable in some two thirds (69 of 108) of infections with streptococci of groups A, C or G. These organisms appeared to have reached the tissues much more often through the skin or exposed tissues than from the respiratory tract. Local skin infection preceded the development of 27 infections (with streptococci of group A, 18; of group C, 2; of group G, 7); it was a cellulitis associated with a trivial or undetected local lesion in 14, a secondary infection of a nonbacterial skin disease in four and of a bedsore or leg ulcer in nine. Two of the 
group-G infections were cases of recurrent cellulitis with bacteriaemia. Sixteen infections followed surgical operations or other surgical procedures. In all, 48 infections appear to have been through the skin or exposed tissues, and in only 16 was there any evidence that the infection may have originated in the respiratory tract. The latter included two cases of group-A streptococcal tonsillitis and one of group-C streptococcal otitis media with septicaemia, and 13 cases of pneumonia or tracheobronchitis only five of which were confirmed by the isolation of the streptococcus from the lung.

The 10 infections with group-B streptococci in which a local predisposing cause was recorded were all in adults; in five infections this was childbirth or abortion and in one other it was pelvic sepsis; in seven (all females) the source of infection was apparently in the abdomen. In enterococcal infections, the most commonly recorded local predisposing event was some form of surgical procedure (11 cases). Eight of the patients had had a recent $S$. faecalis infection of the urinary tract or urological operation; four had sepsis elsewhere in the abdomen. Information about previous catheterisation was often not given.

Infection with $S$. milleri was most often associated with a preceding abdominal infection or operation. Of the 22 cases of cerebral abscess or meningitis due to $S$. milleri, however, a local predisposing cause was mentioned in only one (frontal sinusitis). The evidence linking the isolation of streptococci of the " $\alpha$-haemolytic" taxa. with the supposed local predisposing factor was often tenuous. This was certainly true of the post-operative infections and the five isolations from patients with " pneumonia", but four of the five associations with " other surgical procedures" were confirmed bacteriologically.

Streptococci of groups A, C and G were responsible for 16 of the 52 infections that followed surgical operations and similar procedures on hospital patients, and enterococci for a further 11. The surgical procedures other than conventional operations that were apparently " responsible" for 25 infections were: intravenous cannulation (eight), insertion of a valve into the cerebral ventricle (seven), lumbar puncture (three), peritoneal dialysis (two), and arteriovenous shunt, liver perfusion, insertion of a cardiac pacemaker, gastroscopy with injury to the oesophagus, and blood transfusion (one each). The sequelae included 10 cases of meningitis.

\section{DISCUSSION}

In this investigation we attempted (1) to classify a large collection of streptococci (and a few aerococci) of human origin by an empirically chosen set of tests and (2) to define the ability of organisms in the taxa that could be recognised to cause particular forms of systemic infection. Colman and Williams (1972) examined a collection of $\alpha$-haemolytic and non-haemolytic streptococci serologically, by means of a set of physiological and biochemical tests, and by identifying sugars from the cell wall, and recognised six species: $S$. pneumoniae, $S$. salivarius, $S$. mitior, $S$. milleri, $S$. sanguis and $S$. mutans. We used a shortened set of cultural and biochemical tests, but did not examine the cell-wall composition of our isolates, and found that most of our isolates were classifiable by this 
means. We specifically excluded pneumococci from our series because their identification presents little difficulty. If $S$. bovis and $S$. faecalis are added to the streptococcal species listed by Colman and Williams (1972), we were able to allocate 497 of $592(84.0 \%)$ of the " $\alpha$-haemolytic" and "non-haemolytic" streptococci to one of them; with the addition of 217 serologically identifiable and mainly $\beta$-haemolytic, " pyogenic" streptococci and 11 aerococci, we were able to make a precise identification of 725 of 820 isolates $(88.4 \%)$. We were least successful in classifying the streptococci that belonged to the " $\alpha$ haemolytic " taxa, many of which could not with certainty be allocated either to $S$. sanguis or $S$. mitior by means of our tests; 55 strains remain as "viridans" streptococci of uncertain species, the largest group of unclassified strains in our collection. Had we included cell-wall analysis among our tests, these strains would have been allocated to one or other of the two species according to whether ribitol was present or absent (Colman and Williams, 1965 and 1972).

The cultural and biochemical characters of individual strains in each recognised species or group were, however, far from uniform, and few of the tests were free from occasional anomalous results. Identification of streptococci by means of a dichotomous key would certainly lead to many errors. Many of the tests contributed nothing to the identification of most of the strains (tables III $a$ and III $b$ ). Some system of sequential testing would probably give the same results more economically; we are investigating this possibility in a study of streptococci from a wider variety of sources.

Our second objective, to study the range of pathogenic activity of different streptococci, made it necessary to accumulate a large collection of isolates. Because systemic streptococcal diseases are not common we had to solicit cultures from many different laboratories and to content ourselves with the clinical information provided. This was often very good, but in some cases it was obviously far from complete. In considering our results, therefore, the reported frequencies of positive features in the case histories, e.g., clinical evidence of sepsis in internal organs, a history of previous heart disease, and the presence of other predisposing factors, must be regarded as minimum figures. The cultures sent to us may not have been representative of the organisms that cause systemic infections; they probably included an unduly high proportion of cultures that had proved difficult to identify in the local laboratory, and there may be a corresponding deficiency of easily recognised organisms, such as $S$. faecalis and the "pyogenic" $\beta$-haemolytic streptococci. The referred cultures may also have included an excess of isolates from patients with clearly identifiable diseases, such as endocarditis. It seemed wise, therefore, to draw conclusions whenever possible from comparisons of the frequency of different sorts of streptococci among isolates from patients in separate disease categories, but to be cautious in making generalisations about the frequency with which systemic infection with a particular streptococcus resulted, for example, in endocarditis or meningitis. And finally, the streptococcus isolated may not in every instance have been responsible for the disease from which the patient was suffering. Duma et al. (1969) made a careful study of the case histories of 140 patients from whose blood 154 isolations of distinct streptococcal strains had 
been made, and concluded that only $91(59 \%)$ of the isolations were " definitely significant"; but this series included only six of endocarditis and no neonatal infections, and streptococci from internal organs were excluded unless a positive blood culture had been obtained.

\section{Endocarditis}

Thirty years ago, bacterial endocarditis was mainly a disease of young adults caused by $\alpha$-haemolytic streptococci. Cates and Christie (1951) reported that $62 \%$ of 442 cases of endocarditis studied between 1945 and 1948 were in patients aged between 15 and 35 years; $87 \%$ of the cases were associated with $\alpha$-haemolytic streptococci, $7 \%$ with non-haemolytic streptococci and $6 \%$ with other micro-organisms. In their series, the sexes were equally affected, but there was a slight excess of females among the younger patients and $61 \%$ of the patients aged $>35$ years were male. The disease now occurs more often in the middle-aged and elderly than in the young, and is caused by a much greater variety of organisms, including staphylococci and non-haemolytic streptococci (Uwaydah and Weinberg, 1965; Hughes and Gauld, 1966). Our series of streptococcal isolates from patients with endocarditis came predominantly from patients aged over 35 years and showed a considerable excess of males over females up to the age of 65 years.

In four of five studies of streptococcal endocarditis published between 1946 and 1950 (Hehre and Neill, 1946; Niven and White, 1946; Selbie, Simon and Robinson, 1949; Porterfield, 1950), strains classified as $S$. sanguis and S. mitior together made up more than three-quarters of the total $(77 \%, 83 \%, 92 \%$ and $86 \%$ respectively), and in the fifth (Foley, 1947), in which enterococci predominated, they formed only $32 \%$; in the present series, if members of all " $\alpha$-haemolytic" taxa are included. the percentage was 45 .

Other streptococci that featured prominently in our series of 317 isolates were $S$. bovis, $S$. mutans and, to a lesser extent, $S$. milleri and $S$. faecalis. Although $S$. bovis had been mentioned as a cause of some $10 \%$ of endocarditis cases in three of the five early studies (Niven and White, 1946, 11\%; Foley, $1947,9 \%$; and Porterfield, 1950, 10\%), it received little subsequent attention until Facklam (1972) and Kiel and Skadhauge (1973) described many isolates of the mannitol-fermenting, starch-hydrolysing, dextran-producing variety that we have described as biotype I (see also Ravreby, Bottone and Keusch, 1973; Hoppes and Lerner, 1974; Moellering, Watson and Kunz, 1974; Watanakunakorn, 1974).

S. mutans was described by Clarke in 1924 as the main bacterial cause of dental caries and re-identified several decades later (Carlsson, 1967) with certain streptococcal strains with which this disease can be reproduced experimentally in laboratory animals. In 1928, Abercrombie and Scott reported a single case of endocarditis due to $S$. mutans, but this streptococcus does not appear to have been mentioned again as a cause of the disease until 1974, when Perch, Kjems and Ravn described 54 strains isolated from cases in Denmark between 1959 and 1971 (see also Facklam, 1974; Harder et al., 1974). 
Endocarditis associated with $S$. milleri appears not to have been reported previously, but this streptococcal species has only recently been recognised widely; there were 17 cases in our series. Enterococcal endocarditis is said to have become more common in recent years (Uwaydah and Weinberg, 1965; Finland and Barnes, 1970; Cherubin and Neu, 1971), but this is doubtful. Its reported frequency in earlier years was highly variable; three of the five 1946-50 series previously mentioned include less than $5 \%$ of enterococcal infections, but Hehre and Neill (1946) give a percentage of 17 and Foley (1947) of 56. As long ago as 1909, Horder described eight enterococcal infections among 30 cases of endocarditis $(27 \%)$. Our figure of $6 \%$ is almost certainly an underestimate of the present frequency.

Our 317 isolates included at least one representative of each recognisable taxon. It is generally conceded that many different streptococci can cause endocarditis, but $S$. salivarius is usually considered an exception, and there is some doubt of the ability of aerococci to do so (but see Colman, 1967). In such a large collection of isolates it is inevitable that a few strains that did not cause endocarditis will have been included, and it must be admitted that neither of these organisms was isolated from a heart valve in the present series, and that two of the four aerococci were isolated from patients whose blood cultures also yielded a streptococcus.

When we consider the relative frequency with which different sorts of streptococci were isolated from endocarditis and from other systemic diseases we are probably on firmer ground. The proportion of all streptococci isolated from the blood and internal organs of ill patients that appear to have caused endocarditis varied widely between taxa; this we expressed as a ratio of percentages "endocarditis: no endocarditis". This ratio was $>3: 1$ for four streptococci ( $S$. mutans, $S$. bovis I, $d x+$ mitior strains, and $S$. sanguis), was somewhat lower for $S$. mitior, unclassified "viridans" strains, and several other streptococci, and lowest for $S$. milleri and the groupable "pyogenic" streptococci. Elliott (1973) suggested that dextran production may be a determinant for the ability of $S$. sanguis to adhere to heart valves. Our findings suggest that the other three characteristically dextran-forming taxa (S. mutans, $S$. bovis I, and $d x+$ mitior strains) may possess a similar advantage. The difference between the ratios for $S$. bovis I $(6: 1)$ and $S$. bovis II $(1: 2)$ also appears to conform with this view. Among the streptococci of the " $\alpha$ haemolytic" taxa there is also a close correlation between the "endocarditis ratio " and the formation of dextran in vitro (ratios: $d x+$ sanguis strains, $5: 1$; $d x+$ mitior strains, $3: 1$; all $S$. sanguis, $3: 1$; $S$. mitior $(d x-), 2: 1$; unclassified "viridans" strains, $1: 1$ ). These findings tend to suggest that, if pathogenesis should be accorded any weight in bacterial classification, Colman and Williams (1972) were correct in separating the $d x+$ mitior strains from $S$. mitior, and that a more strict definition of $S$. sanguis to include only $d x+$ strains might similarly be justifiable. If, indeed, dextran aids the establishment of streptococci on the heart valve by its "stickiness " (Lancet, 1974) this must be by virtue of pre-formed polysaccharide, because the organism is unlikely to produce more after entering the bloodstream. 
Our findings throw some light on the changed age incidence of endocarditis. In the rather small group of 39 patients aged 10-34 years, streptococci of the " $\alpha$-haemolytic" taxa were responsible for $69 \%$ of infections, not much less than the combined percentage of $S$. sanguis and $S$. mitior in four of the five 1946-50 reports. The number of streptococcal isolates from cases of endocarditis per 10-year cohort increased steadily up to the age of 65 years, and the number of " $\alpha$-haemolytic " isolates remained constant or rose slightly, but the number of isolates of other streptococci rose steeply. Consequently the percentage of " $\alpha$-haemolytic" streptococci fell with increasing age. Among the streptococci that were isolated mainly from the older patients, S. bovis I was associated with nearly one-quarter of the cases in patients aged $>55$ years. This organism, unlike $S$. mutans and the " $\alpha$-haemolytic" streptococci, is not found in the mouth (Phillips et al., 1976). Information about the presence of $S$. bovis in the gut flora is incomplete (Mieth, 1961) and does not distinguish between the two human biotypes.

Patients with endocarditis associated with " $\alpha$-haemolytic" streptococci gave a history of previous damage to or abnormality of the heart more often than did other patients with streptococcal endocarditis, but the information available did not permit us to draw conclusions about the frequency with which this was rheumatic or congenital, or about the importance of recent dental extraction in the initiation of the disease. Other predisposing factors-such as major underlying disease or surgical procedures-appeared seldom to have been of importance, except in a few cases, mainly of infection with pyogenic streptococci, enterococci and $S$. milleri.

Antibiotic resistance is unlikely to have been a major cause of changes in the aetiology of endocarditis. Of the streptococci responsible for the disease, only $S$. faecalis is regularly resistant to a wide range of antibiotics; the " new" endocarditis streptococci $S$. mutans, $S$. bovis I, and $S$. milleri are sensitive to all common antibiotics except the aminoglycosides and sometimes tetracycline; occasional " $\alpha$-haemolytic" streptococci may in addition be moderately resistant to penicillin, erythromycin, clindamycin or rifampicin, but " multiple "antibiotic resistance is rare (Phillips et al., 1975 and 1976).

Apparent changes during the last 30 years in the aetiology of streptococcal endocarditis are probably a reflexion of differences in the age composition of the hospital population and the growing recognition of the existence of endocarditis in the elderly (Hayward, 1973). If, as Uwaydah and Weinberg (1965) suggest, it often becomes established on atheromatous lesions in the heart, which may not have been clinically apparent before the onset of the disease, its frequency in previously healthy old people is explicable.

\section{Purulent diseases}

In nearly one-third of all the patients suffering from purulent diseases, $S$. milleri was isolated from an internal organ or the blood; it constituted a similar proportion of all streptococcal isolates from septic lesions in internal organs. This activity of $S$. milleri appears not to have been recorded before, 
but the organism is nondescript in colonial appearances and may attract attention only if it is $\beta$-haemolytic or belongs to a Lancefield group. It often grows poorly or not at all in the absence of $\mathrm{CO}_{2}$; many of the strains submitted to us had initially been described as "micro-aerophilic" or " anaerobic" streptococci. Meningitis, peritonitis, pleural empyema and bacteriaemia caused by group-F streptococci (Rantz, 1942; Wheeler and Foley, 1943; Foley, 1947; Koepke, 1965; Wort, 1975) or by non-haemolytic, bacitracinresistant group-A streptococci (Bannatyne and Robson, 1974) have been described; these organisms are very likely to have been $S$. milleri.

The source of these infections is uncertain. Ottens and Winkler (1962) found many strains of $S$. milleri in the dental root-canal, and we found them often on the surface of the teeth and on sutures removed after dental operations (Phillips et al., 1976). The anatomical distribution of the lesions in our series suggests that the source of a considerable number of them was in the abdomen, a conclusion reached by Wort (1975) from a study of group-F infections. Studies of the distribution of $S$. milleri in the gut have not been made, but Rogers (1957) isolated group-F streptococci from $11 \%$ of acutely inflamed appendices. Whether infections of the central nervous system arise from the respiratory tract has yet to be established.

\section{Factors predisposing to systemic streptococcal infection other than endocarditis}

Although general or local predisposing factors-other than previous heart damage and dental extraction-appear to play little part in initiating endocarditis, the situation appears to be different with the other systemic streptococcal infections. We found that $14 \%$ of the patients with purulent or bacteriaemic infections had a serious underlying disease, and that in one-half of these it was carcinoma, leukaemia, Hodkgin's disease, agranulocytosis or diabetes mellitus. In many cases, however, it was uncertain whether this had acted as a general predisposing cause or provided a point of entry for the infecting streptococcus. Most of the resulting infections were clear-cut septicaemic episodes caused by streptococci with known invasive properties (members of groups A, B, C or G, $S$. milleri or enterococci), but in some of the instances in which " $\alpha$-haemolytic" streptococci were isolated from the blood of seriously ill patients this may well have been an incidental finding. The only certain effect of age on general susceptibility to infection was the well known predominance of group-B infections in newborn infants. The more modest increase in the frequency of pyogenic infections-other than with group B streptococci-after the age of 55 years may well be attributable to local predisposing factors.

There was evidence-rather variable in quality-for a portal of entry in $40 \%$ of all " non-endocarditis" infections (with streptococci of groups A, C or G, 68\%; with enterococci, $66 \%$; with $S$. milleri, 33\%). The rather low frequency with which this evidence was obtained in infections with group-B streptococci is explained by the fact that over half of the patients were infants, in whom the point of entry of the organism is seldom ascertained; nevertheless, there were several instances in which previously healthy adults-including 
some males-developed septicaemia due to this organism. The isolations of " $\alpha$-haemolytic" streptococci from ill patients after a surgical operation or in the presence of a respiratory-tract infection was often of uncertain significance. In summary, it may be said that (1) "pyogenic" streptococci of groups A, C and $\mathrm{G}$ appeared to gain entry more often from the skin or through a wound than from the respiratory tract, (2) that the point of entry of group-B streptococci, and $S$. milleri, when determined, was usually intra-abdominal, and (3) that enterococcal infection arose from an intra-abdominal source or followed one of a variety of surgical or similar procedures.

It was difficult to assess realistically the proportion of infections that could be attributed directly to the hospital or to " hospital " procedures. Duma and his colleagues (1969), from a very careful examination of the evidence, concluded that 36 of 91 incidents of streptococcal bacteriaemia in a single hospital were " nosocomial" in origin. Their series was mainly of elderly patients suffering from other serious underlying diseases and included only six cases of endocarditis. In that situation it is difficult to disentangle the effects of pre-existing disease from the consequences of its treatment. A considerable proportion of our " non-endocarditis" patients suffered a systemic streptococcal infection "after" a specific hospital procedure, and in many instances a direct causal relationship could be established. There was seldom direct evidence, however, that the source of the infecting organism was extraneous to the patient; and most of these instances concerned group-A streptococci.

\section{SUMMARY}

A collection of 820 isolates of streptococci and aerococci from human blood or internal organs was classified by means of a set of cultural and biochemical tests. Of these, 719 (712 streptococci and 7 aerococci) were from patients believed to be suffering from a systemic infection: endocarditis 317 ; a purulent lesion in an internal organ (" purulent disease ") 152; bacteriaemia 250.

The endocarditis streptococci included members of all recognisable taxa, but only certain of these were common: Streptococcus sanguis, $16 \cdot 4 \%$; dextranpositive and usually mannitol-fermenting strains of $S$. bovis (S. bovis I), $15.1 \%$; S. mutans, $14 \cdot 2 \%$; S. mitior, $13 \cdot 2 \%$. Streptococci of the " $\alpha$-haemolytic" taxa (S. sanguis, S. mitior and related strains) formed only $44.8 \%$ of the total. When the percentage frequency of streptococcal taxa among the endocarditis and "non-endocarditis" isolates was compared, the dextran-forming taxa (S. mutans, S. bovis I, S. sanguis, and dextran-positive streptococci otherwise resembling $S$. mitior) all had higher " endocarditis : non-endocarditis "ratios than did any of the non-dextran-producing taxa.

Endocarditis increased in frequency with age, and showed an excess of males over females up to the age of 65 years. In young patients ( $<35$ years), " $\alpha$-haemolytic" streptococci predominated; with increasing age, the proportion of other streptococci increased progressively but the absolute numbers of isolations of " $\alpha$-haemolytic" streptococci did not fall. Infections with $S$. mutans were prominent in the age-group 35-54 years and with $S$. bovis I at ages 
$>55$ years. A history of previous heart disease was more often obtained in endocarditis due to " $\alpha$-haemolytic" streptococci than in other streptococcal endocarditis.

The streptococcus most often isolated from purulent lesions in internal organs was $S$. milleri $(29 \cdot 3 \%$ ). It was associated with brain abscess, meningitis, pleural empyema and a variety of intra-abdominal abscesses.

The only common predisposing factor in endocarditis was previous heart damage. In other systemic streptococcal diseases, other general or local predisposing causes could be observed, mainly in infections with the " pyogenic" groupable streptococci, the enterococci and $S$. milleri.

We wish to thank our many colleagues in hospital and public health laboratories for cultures and clinical histories, the Epidemiological Research Laboratory, Central Public Health Laboratory, for giving us access to information from their current study of " significant bacteriaemia ", Dr W. R. Maxted and Miss C. A. M. Fraser for much practical assistance, and Dr G. Colman and Professor I. Phillips for valuable discussions.

\section{REFERENCES}

Abercrombie, G. F. AND Scott, W. M. 1928. A case of infective endocarditis due to Streptococcus mutans. Lancet, $2,697$.

ANDREWES, F. W. AND HoRDER, T. J. 1906. A study of the streptococci pathogenic for man. Lancet, $2,708$.

BaIley, R. W. AND OXford, A. E. 1958. Pre-requisites for dextran production by Streptococcus bovis. Nature, Lond., 182, 185.

Bannatyne, R. M. AND Robson, A. 1974. Bacteremia due to atypical streptococci belonging to Lancefield group A. Report of two cases. Am. J. clin. Path., 61, 358.

BARNes, E. M. 1956. Tetrazolium reduction as a means of differentiating Streptococcus faecalis from Streptococcus faecium. J. gen. Microbiol., 14, 57.

Bateman, N. T., Eykyn, S. J. AND Phillips, I. 1975. Pyogenic liver abscess caused by Streptococcus milleri. Lancet, 1, 657.

Bratthall, D. 1970. Demonstration of five serological groups of streptococcal strains resembling Streptococcus mutans. Odont. Revy, 21, 143.

Carlsson, J. 1967. Presence of various types of non-haemolytic streptococci in dental plaque and in other sites of the oral cavity in man. Odont. Revy, 18, 55.

CAtes, J. E. AND Christie, R. V. 1951. Subacute bacterial endocarditis. A review of 442 patients treated in 14 centres appointed by the Penicillin Trials Committee of the Medical Research Council. Q. Jl Med., 20 (n.s.), 93.

Cherubin, C. E. AND Neu, H. C. 1971. Infective endocarditis at the Presbyterian Hospital in New York City from 1938-1967. Am. J. Med., 51, 83.

Clarke, J. K. 1924. The bacterial factor in the aetiology of dental caries. Br. J. exp. Path., $5,141$.

Clarke, P. H. 1953. Growth of streptococci in a glucose phenolphthalein broth. J. gen. Microbiol., 9, 350.

Colman, G. 1967. Aerococcus-like organisms isolated from human infections. J. clin. Path., 20, 294.

Colman, G. 1968. The application of computers to the classification of streptococci. J. gen. Microbiol., 50, 149.

Colman, G. 1969. Transformation of viridans-like streptococci. J. gen. Microbiol., 57, 247.

Colman, G. 1970. The classification of streptococcal strains. Ph.D. Thesis, University of London.

Colman, G. And Williams, R. E. O. 1965. The cell walls of streptococci. J. gen. Microbiol., 41, 375. 
Colman, G. and Williams, R. E. O. 1972. Taxonomy of some human viridans streptococci. In Streptococci and streptococcal diseases; recognition, understanding and management, edited by L. W. Wannamaker and J. M. Matsen, New York and London, p. 281.

Cowan, S. T. AND Steel, K. J. 1974. Manual for the identification of medical bacteria, 2nd ed., edited by S. T. Cowan, London.

CoYkendall, A. L. 1974. Four types of Streptococcus mutans, based on their genetic, antigenic and biochemical characteristics. J. gen. Microbiol., 83, 327.

Duma, R. J., Weinberg, A. N., Medrek, T. F. AND KunZ, L. J. 1969. Streptococcal infections: a bacteriologic and clinical study of streptococcal bacteremia. Medicine, Baltimore, 48, 87.

ELLIOTT, S. D. 1973. The incidence of group-H streptococci in blood cultures from patients with subacute bacterial endocarditis (SBE). J. med. Microbiol., 6, p. xiv.

FACKLAM, R. R. 1972. Recognition of group D streptococcal species of human origin by biochemical and physiological tests. Appl. Microbiol., 23, 1131.

FACKLAM, R. R. 1974. Characteristics of Streptococcus mutans isolated from human dental plaque and blood. Int. J. syst. Bact., 24, 313.

Finland, M. AND BARNES, M. W. 1970. Changing aetiology of bacterial endocarditis in the antibacterial era: experience at Boston City Hospital 1933-65. Ann. intern. Med., 72, 341 .

FoLEY, G. E. 1947. Further observations on the occurrence of streptococci of groups other than A in human infection. New Engl. J. Med., 237, 809.

Fuller, A. T. 1938. The formamide method for the extraction of polysaccharides from haemolytic streptococci. Br.J. exp. Path., 19, 130.

Harder, E. J., Wilkowske, C. J., Washington, J. A. II and Geraci, J. E. 1974. Streptococcus mutans endocarditis. Ann. intern. Med., 80, 364.

HAYWARD, G. W. 1973. Infective endocarditis: a changing disease. Br. med. J., 2, 706, 764.

Hehre, E. J. AND NeILl, J. M. 1946. Formation of serologically reactive dextrans by streptococci from subacute bacterial endocarditis. J. exp. Med., 83, 147.

HOPPES, W. L. AND LERNER, P. I. 1974. Nonenterococcal group-D streptococcal endocarditis caused by Streptococcus bovis. Ann. intern. Med., 81, 588.

HORDER, T. J. 1909. Infective endocarditis with an analysis of 510 cases and with special reference to the chronic form of the disease. Q.J. Med., $2,289$.

Hughes, P. AND GAULD, W. R. 1966. Bacterial endocarditis: a changing disease. Q.Jl Med., 35, (n.s.), 511.

KIEL, P. AND SKadhauge, K. 1973. Studies on mannitol-fermenting strains of Streptococcus bovis. Acta. path. microbiol. scand., B81, 10.

KOEPKE, J. A. 1965. Meningitis due to Streptococcus anginosus (Lancefield group F). J. Am. med. Ass., 193, 739.

LANCEFIELD, R. C. 1928. The antigenic complex of Streptococcus haemolyticus. I. Demonstration of a type-specific substance in extracts of Streptococcus haemolyticus. J. exp. Med., 47, 91 .

LANCET (LEADING ARTICLE). 1974. Bacterial stickiness. Lancet, 1, 716.

MAXTED, W. R. 1948. Preparation of streptococcal extracts for Lancefield grouping. Lancet, $2,255$.

MEDReK, T. F. AND BARNES E. M. 1962. The influence of the growth medium on the demonstration of a group D antigen in faecal streptococci. J. gen. Microbiol., 28, 701.

MIETH, H. 1961. Untersuchungen über das Vorkommen von Enterokokken bei Tieren und Menschen. II. Ihr Vorkommen in Stulhproben von gesunden Menschen. Zentbl. Bakt. ParasitKde, I Abt. Orig., 183, 68.

Mollering, R. C. JR, WATson, B. K. AND Kunz, L. J. 1974. Endocarditis due to group D streptococci. Comparison of disease caused by Streptococcus bovis with that produced by the enterococci. Am. J. Med., 57, 239.

Niven, C. F. JR, Smiley, K. L. AND Sherman, J. M. 1942. The hydrolysis of arginine by streptococci. J. Bact., 43, 651 . 
Niven, C. F. JR, AND White, J. C. 1946. A study of streptococci associated with subacute bacterial endocarditis. J. Bact., 51, 790.

OTTENS, H. AND WINKLER, K. C. 1962 . Indifferent and haemolytic streptococci possessing group antigen F. J. gen. Microbiol., 28, 181.

Perch, B., KJems, E. ANd Ravn, T. 1974. Biochemical and serological properties of Streptococcus mutans from various human and animal sources. Acta. path. microbiol. scand., B82, 357.

Phillips, I., Warren, C., Ball, L. C. and Parker, M. T. 1975. Antibiotic susceptibility of streptococci isolated from blood. J. med. Microbiol., 8, p. v.

Phillips, I., Warren, C., Harrison, J. M., Sharples, P., Ball, L. C. and Parker, M. T. 1976. Antibiotic susceptibilities of streptococci from the mouth and blood of patients treated with penicillin or lincomycin and clindamycin. J. med. Microbiol., 9, in the press.

PoRTERfIeld, J. S. 1950. Classification of the streptococci of subacute bacterial endocarditis. J. gen. Microbiol., 4, 92.

RANTZ, L. A. 1942. Streptococcal meningitis: four cases treated with sulphonamides in which the aetiological agent was an unusual streptococcus. Ann. intern. Med., 16, 716.

RAVREBY, W. D., BotTone, E. J. AND KeUSCH, G. T. 1973. Group D streptococcal bacteremia, with emphasis on the incidence and presentation of infections due to Streptococcus bovis. New Engl. J. Med., 289, 1400.

Rogers, K. B. 1957. The association of acute appendicitis with infective diarrhoea. Proc. R. Soc. Med., 50, 1025.

RotTa, J., Krause, R. M., Lancefield, R. C., Everly, W. and Lackland, H. 1971. New approaches for the laboratory recognition of $\mathrm{M}$ types of group A streptococci. J. exp. Med., 134, 1298.

SchotmülleR, H. 1903. Die Artunterscheidung der für den Menschen pathogenen Streptokokken durch Blutagar. Münch. med. Wschr., 50, 849.

Selbie, F. R., Simon, R. D. AND Robinson, R. H. M. 1949. Serological classification of viridans streptococci from subacute bacterial endocarditis, teeth and throats. $B r$. med. J., $2,667$.

SHARPE, M. E. 1964. Serological types of Streptococcus faecalis and its varieties and their cell wall type antigen. J. gen. Microbiol., 36, 151.

Shatтock, P. M. F. 1949. The streptococci of group D: the serological grouping of Streptococcus bovis and observations on serologically refractory group D strains. J. gen. Microbiol., 3, 80.

Shattock, P. M. F. ANd Hirsch, A. 1947. A liquid medium buffered at $p \mathrm{H} 9.6$ for the differentiation of Streptococcus faecalis from Streptococcus lactis. J. Path. Bact., 59, 495.

UWAYDAH, M. M. AND WEINBERG, A. N. 1965. Bacterial endocarditis-a changing pattern. New Engl. J. Med., 273, 1231.

WATANAKUNAKORN, C. 1974. Streptococcus bovis endocarditis. Am.J. Med., 56, 256.

WheEler, S. M. AND Foley, G. E. 1943. A note on non-group A streptococci associated with human infection. J. Bact., 46, 391.

White, J. C. AND NIven, C. F. JR 1946. Streptococcus S.B.E.: a streptococcus associated with subacute bacterial endocarditis. J. Bact., 51, 717.

Wuliams, R. E. O. 1958. Laboratory diagnosis of streptococcal infections. Bull. Wld Hlth Org., 19, 153.

Williams, R. E. O., Hirch, A. AND Cowan, S. T. 1953. Aerococcus, a new bacterial genus. J. gen. Microbiol., 8, 475.

WoRT, A. J. 1975. Observations on group-F streptococci from human sources. J. med. Microbiol., 8, 455. 